\title{
AUTHENTICATION OF COMMERCIAL CHILEAN MOLLUSKS USING RIBOSOMAL INTERNAL TRANSCRIBED SPACER(ITS)AS SPECIE-SPECIFIC DNA MARKER
}

\author{
AUTENTIFICACION DE MOLUSCOS COMERCIALES CHILENOS USANDO \\ ESPACIADORES INTERNOS TRANSCRITOS (ITS) COMO UN MARCADOR DE \\ ADNESPECIE-ESPECIFICO
}

\author{
Felipe Aguilera-Muñoz, Valentina Valenzuela-Muñoz \& Cristian Gallardo-Escárate \\ Laboratorio de Biotecnología Acuícola, Centro de Biotecnología, Departamento de Oceanografía, Universidad de \\ Concepción. Barrio Universitario s/n. Casilla 160-C Concepción, Chile \\ E-mail: cristian.gallardo@udec.cl (C. Gallardo-Escárate)
}

\begin{abstract}
Contemporary world food safety standards have emphasized the implementation of efficient food traceability systems, including the correct labeling of products for the authentication of the commercialized species. In this context, Chile has reached an important development in agricultural exportations, reaching near US\$ 3.82 billion in 2007. Since the identification based on morphologic and organoleptic characteristics is complex during the elaboration process of aquaculture products, molecular tools need to be developed in order to genetically trace aquaculture products. This study analyzed five species of Chilean commercial mollusks using molecular DNA markers. From the partial sequences of the ribosomal region ITS1-5.8SrDNA-ITS2, the specific primers for the internal transcribed spacers 1 and 2 (ITS1, ITS2) were designed. These primers in 8 fresh species of mollusks, 5 commercial presentations and 3 processed species, obtaining specie-specific band patterns in all cases for both ITS. Additionally, the primers are shown to be highly specific and of replicable amplification products, independently from the commercial presentation of the studied species. Genetically trace aquaculture products. The presence of fraud for species substitution between canned abalone (Haliotis) and loco (Concholepas) species is discussed.
\end{abstract}

KEYworDs: Genetic traceability, ITS1, ITS2, mollusk identification, specific divider design.

\section{RESUMEN}

Las actuales regulaciones a nivel mundial sobre seguridad alimentaria han enfatizado la implementación de sistemas eficientes de trazabilidad alimentaria, así como el correcto etiquetado de productos para la autentificación de las especies comercializadas. En este contexto, Chile ha alcanzado un importante desarrollo en acuicultura con exportaciones cercanas a los US\$ 3.826,8.- millones en el año 2007. Debido al proceso de elaboración de productos acuícolas, la identificación basada en características morfológicas y organolépticas es compleja, siendo necesario el desarrollo de herramientas moleculares como mecanismo para la trazabilidad genética de productos acuícolas. En éste estudio, se analizaron 5 especies de moluscos comerciales chilenos mediante marcadores moleculares ADN. A partir de secuencias parciales de la región ribosomal ITS1-5.8SADNr-ITS2 se realizó el diseño de partidores específicos para los espaciadores internos transcritos 1 y 2 (ITS1, ITS2). Los partidores diseñados fueron validados en 8 especies frescas de moluscos, 5 presentaciones comerciales y 3 especies procesadas obteniéndose patrones de bandeo especie-específicos en todos los casos para ambos ITS. Los partidores diseñados mostraron ser altamente específicos y de productos de amplificación replicable independientemente de la presentación comercial de las especies estudiadas. La utilización de los partidores para las regiones ITS permite su aplicación en trazabilidad genética de productos acuícolas. Se discute la presencia de fraude por sustitución de especies entre abalón (Haliotis) y loco (Concholepas) enlatados.

Palabras claves: Trazabilidad genética, ITS1, ITS2, identificación de moluscos, diseño de partidores específicos. 


\section{INTRODUCTION}

Fishing and aquaculture form part of the principal productive and economic activities in Chile. In 2007, total exports from this sector reached 1.413 billion tons for a value of US\$ 3.826 billion; these values are an increase of 1.6 and $3.9 \%$ respectively (SUBPESCA 2007). In aquaculture production, Chile is among the ten most important aquaculture countries world wide: it is the second world salmon producer and an emerging exporter of seaweeds and mollusks, where the gastropods are one of the most economically important group of species. One example are abalones (Haliotis): Chile was the 5th producer at a world wide level in 2006 (Flores-Aguilar et al. 2007).

One of the main challenges for aquaculture at a world level is the certification of the quality and harmlessness of the food products in the final markets. Beginning in 2005, food sector companies, including aquaculture, should develop and implement norms and procedures of animal identification and traceability in accordance with the European Regulation 178/2002, The Bio-Terrorism Law and the COOL Mandate ("Country of Origin Labeling”) from the United States (Thompson et al. 2005) and the European Union. Regattieri et al. (2007) define the term traceability as the capacity to reconstruct the history that a product possesses in terms of the intrinsic properties and/or the properties associated to this after it has been subject to a particular process of addition of added value. In this sense, when food products are processed (i.e. under high temperatures, addition of chemical compounds and high pressure), identification by morphological characteristics is insufficient and there can be cases of species substitution or commercial fraud. In these cases, DNA characteristics are more thermo-stable in comparison with the proteins because they are present in all of the cells of an organism, making it a powerful tool in animal authentication (Bossier 1999; Lockley \& Bardsley 2000).

The authentication of species using DNA creates the possibility of genetic traceability, which is defined as the ability to identify the origin of an organism or food product, as far away from the production chain as necessary, and monitoring or tracking the same based on its genetic fingerprint, or DNA (Cunningham \& Meghen 2001). A few of the molecular markers used in the authentication of commercial species are the mitochondrial genes $12 \mathrm{~S}$ rRNA, 16S rRNA (Borgo et al. 1996; Abdulmawjood \& Bülte 2001; Chapela et al. 2002; Di-Finizio et al. 2007), cytochrome $b$ (Unseld et al. 1995; Ram et al. 1996; Quinteiro et al. 1998; Cocolin et al. 2000; Chapela et al. 2003), cytochrome oxidase II (Carrera et al. 1999). Studies on species authentication with nuclear markers are rare and only refer to PCR-RFLP of the 18S rDNA gene and internal transcribed spacers (Fernández et al. 2001; López-Piñón et al. 2002; Santaclara et al. 2006). However, since the characteristics of the ITS are relatively variable in nucleotide composition and longitude for different species, localized zones at the interior of the ITS can be used as a robust marker at a specific level (Fernández et al. 2001; Coleman \& Vacquier 2002; Coleman 2003; Insúa et al. 2003; HanLiang et al. 2006).

The objective of this study was to design and evaluate species-specific primers for the amplification of the ITS1 and ITS2 regions of commercially important mollusks in Chile. The primers were validated by authenticating fresh/frozen as well as canned and processed products.

\section{MATERIALS AND METHODS}

OBTAINING THE SAMPLES

The species used for the primers design were Haliotis rufescens, $H$. discus hannai, Fissurella crassa, Tegula atra and Choromytilus chorus. The samples were obtained between August and September of 2007. The mollusks obtained are summarized in Table I. The obtained sequences of ITS1 and ITS2 were submitted to GenBank under the following access numbers: EU636214EU636218 (Aguilera-Muñoz \& Gallardo-Escárate 2008).

DNA EXTRACTION, AMPLIFICATION AND SEQUENCE The total genomic DNA was extracted from the muscular tissue (foot) using an E.Z.N.A Tissue DNA kit (Omega Bio-Tek, USA) according to the manufacturer's instructions. The extracted DNA was visualized by electrophoresis at a voltage of $70 \mathrm{v}$ for $45 \mathrm{~min}$ in an agarose gel at $1 \%$ in TAE buffer staining with ethydium bromide; the size of the extracted DNA was compared with a molecular weight marker of 1 bk (New England BioLabs ${ }^{\circledR}$ ). 
The gel was observed through a digital photodocumentation system Ultracam ${ }^{\circledR}$ (Model 4883) under ultraviolet light. The quantity and purity of the extracted DNA was measured using a spectrophotometer ND1000 (NanoDrop ${ }^{\circledR}$ Technologies).

The ribosomal region ITS1-5.8SrDNA-ITS2 was amplified by PCR, the primers used were G-FOR (5'GGGATCCGTTTCCGTAGGTGAACCTGC-3') and GREV (5' - GGGATCCATATGCTTAAGT TCAGCGGGT-3') (Coleman \& Vacquier 2002). The PCR reactions were carried out in a final volume of $12.5 \mu \mathrm{L}$, where each reaction contains a PCR $1 \mathrm{X}$ buffer (New England BioLabs ${ }^{\circledR}$ ), $0.2 \mu \mathrm{g} / \mu \mathrm{L}$ BSA, 200 $\mu \mathrm{M}$ dNTP's, $0.5 \mu \mathrm{M}$ of each primer, $0.1 \mathrm{U} / \mu \mathrm{L}$ Taq
DNA Polimerase (New England BioLabs ${ }^{\circledR}$ ), water miliQ and $8 \mathrm{ng} / \mu \mathrm{L}$ of genomic DNA. The PCR conditions were: an initial denaturalization at $94^{\circ} \mathrm{C}$ for $2 \mathrm{~min} 30 \mathrm{sec}$, followed by 35 cycles at $94^{\circ} \mathrm{C}$ for 40 sec, $56^{\circ} \mathrm{C}$ for $40 \mathrm{sec}$ and $72^{\circ} \mathrm{C}$ for $1 \mathrm{~min}$, with a final extension at $72^{\circ} \mathrm{C}$ for 5 minutes. The amplified products were visualized in agarose gel at $1 \%$ under ultraviolet light. The PCR products were purified and sequenced in a bi-directional form in an automatic sequencer ABI 3700 (Applied Biosystems $^{\circledR}$ ) from Macrogen Inc. (Korea). The sequences were verified using chromatograms in the software MEGA4 (Tamura et al. 2007) and aligned using the CLUSTALW method (Higgins et al. 1994).

TABLE I. Species and food products, type of presentation and origin of the samples used in this study.

TABLA I. Especies y productos alimenticios, tipo de presentación y origen de los ejemplares utilizados en el presente estudio.

\begin{tabular}{lcl}
\hline Specie and food product & Type of product & \multicolumn{1}{c}{ Origin } \\
\hline Haliotis rufescens & Fresh & Coquimbo, Chile \\
Haliotis discus hannai & Fresh & Coquimbo, Chile \\
Concholepas concholepas & Fresh & Concepción, Chile \\
Thais chocolata & Fresh & Antofagasta, Chile \\
Chorus giganteus & Fresh & Concepción, Chile \\
Fissurella crassa & Fresh & Concepción, Chile \\
Tegula atra & Fresh & Concepción, Chile \\
Choromytilus chorus & Fresh & Concepción, Chile \\
Oro del Pacifico & Canned & Baja California, México \\
Supreme & Canned & Rayong, Finland \\
Don Efe Super Extra & Canned & Baja California, México \\
Don Efe & Canned & Baja California, México \\
Robinson Crusoe (loco) & Canned & Concepción, Chile \\
Thais chocolata & Processed & Concepción, Chile \\
Chorus giganteus & Processed & Concepción, Chile \\
Tegula atra & Processed & Concepción, Chile \\
\hline
\end{tabular}

DESIGN OF SPECIFIC-PRIMERS FOR THE INTERNAL TRANSCRIBED SPACERS (ITS1 AND ITS2)

Based on the sequence analysis of the ribosomal region ITS1-5.8SrDNA-ITS2, specific primers for the ITS1 and ITS2 were designed using the software DNAMAN 4.03 (Lynnon Biosoft, Quebec, Canada). Two primers that unite the ribosomal 5.8S gene were designed for the amplification of the internal transcribed spacers 1 and 2, respectively. In the case of the ITS1, only the primer reverse that unites the 5 ' extreme of the 5.8SrDNA gene was designed; in contrast, for the ITS2, the primer forward was design that unites the 3' extreme of the 5.8SrDNA gene.

VALIDATION OF THE PRIMERS DESIGNED FOR THE AMPLIFICATION OF ITS1 AND ITS2

The internal transcribed spacers (ITS1 and ITS2) were amplified using the primers designed according to the previous point. The PCR reaction conditions were the previously mentioned and the PCR program for both ITS1 and ITS2 consisted in: an initial denaturalization at $95^{\circ} \mathrm{C}$ for 2 minutes 30 
sec, followed by 35 cycles a $94^{\circ} \mathrm{C}$ for $45 \mathrm{sec}, 54^{\circ} \mathrm{C}$ for $45 \mathrm{sec}$ and $72^{\circ} \mathrm{C}$ for $1 \mathrm{~min}$, with a final extension at $72^{\circ} \mathrm{C}$ for $5 \mathrm{~min}$. The amplified products were visualized with electrophoresis at a voltage of $70 \mathrm{v}$ for $45 \mathrm{~min}$ in an agarose gel at $1 \%$ and the size of the PCR product was compared with a molecular weight marker of 100 bp (New England BioLabs ${ }^{\circledR}$ ). The allele size was assigned with the software Gel-Pro Analyzer (Media Cybernetics, Inc).

\section{RESULTS}

Figure 1 shows the alignment of the ribosomal region ITS1-5.8SrDNA-ITS2 for the commercialized mollusk species in Chile. The primers used for the amplification of the ITS region (Coleman \& Vacquier 2002) are united in highly conserved zones of the ribosomal genes of the subunit greater 28SrDNA and 18SrDNA, allowing amplification of the ITS1-5.8SrDNA-ITS2 complex. In this study, the primers designed are joined in highly conserved zones of the ribosomal gene 5.8SrDNA (Table II). To amplify ITS1, the primer forward used were those proposed by Coleman, Vacquier (2002), which are joined at the 3 ' extreme of the 18SrDNA gene; the primer reverse used was the one proposed in this study and at the
5' extreme of the 5.8SrDNA gene. To amplify ITS2, the primer forward are those proposed in this study and are annealing at the 3' extreme of the 5.8SrDNA gene; the primer reverse is the one proposed by Coleman Vacquier (2002) which joins at the 5' extreme of the 28SrDNA gene (Figure 2). The amplification of ITS1 from fresh products is shown in Figure 3. Fragments near 370 bp were obtained for the halitosis; for C. concholepas, T. chocolate, Ch. giganteus, F. crassa, T. atra, Ch. Chorus, values of 360, 310, 330, 320, 280 y 380 base pairs were found, respectively. In reference to the elaborated products (canned and processed), fragments of similar sizes (280-370 bp) were obtained (Figure 4). The ITS2 fragments from the fresh products are shown in Figure 5, where fragments between 370-570 bp were obtained; for the elaborated products (canned and processed), fragments with sizes that varied between 380-570 bp were obtained (Figure 6). Analysis of the amplifications of both ITS indicate that the cans with the labels Don Efe and Don Efe Super Extra have the same allelic size as the Robinson Crusoe can. When comparing these same canned products with the fresh products, the canned species corresponds to Concholepas concholepas (loco), which is fraud by substitution of a related species that has a lower commercial value.

TABLE II. Primers designed for the amplification of the internal transcribed spaces (ITS1 and ITS2) with their content $\mathrm{G}+\mathrm{C}$.

TABLA II. Partidores diseñados para la amplificación de los espaciadores internos transcritos (ITS1 e ITS2) con su contenido $\mathrm{G}+\mathrm{C}$.

\begin{tabular}{lllll}
\hline Marker & Primer & Sequence (5’-3') & G+C & Reference \\
\hline ITS1 & G-FOR & GGGATCCGTTTCCGTAGGTGAACCTGC & $59.3 \%$ & (Coleman \& Vacquier 2002) \\
ITS1 & F-REV & CCCCCGTCTAGAGTTGTGAGA & $57.1 \%$ & This study \\
ITS2 & F-FOR & GCCTGTCTGAGGGTCGGCGA & $70.0 \%$ & This study \\
ITS2 & G-REV & GGGATCCATATGCTTAAGTTCAGCGGGT50.0\% & (Coleman \& Vacquier 2002) \\
\hline
\end{tabular}

\section{DISCUSSION}

Many authors indicate that the exposure of food of animal origin to industrial processes, such as cooking and sterilizing cans, results in protein structure changes and integrity losses at a genomic level. Given that the DNA is more thermo-stable than proteins at temperatures above $100^{\circ} \mathrm{C}$, the principal effect on the DNA is the fragmentation in the double strain between 100 and 500 bp (Chikuni et al. 1990; Unseld et al. 1995; Ram et al. 1996; Quinteiro et al. 1998). Additionally, when the fragmentation of the DNA does not result in loss of sequences lower than $500 \mathrm{bp}$, amplifications for PCR can be obtained from elaborated products of animal origin. At a specific level, it is possible to flank regions of interest, where sequence variety can exist independently from nucleotide diversity. 
Gayana 72(2), 2008

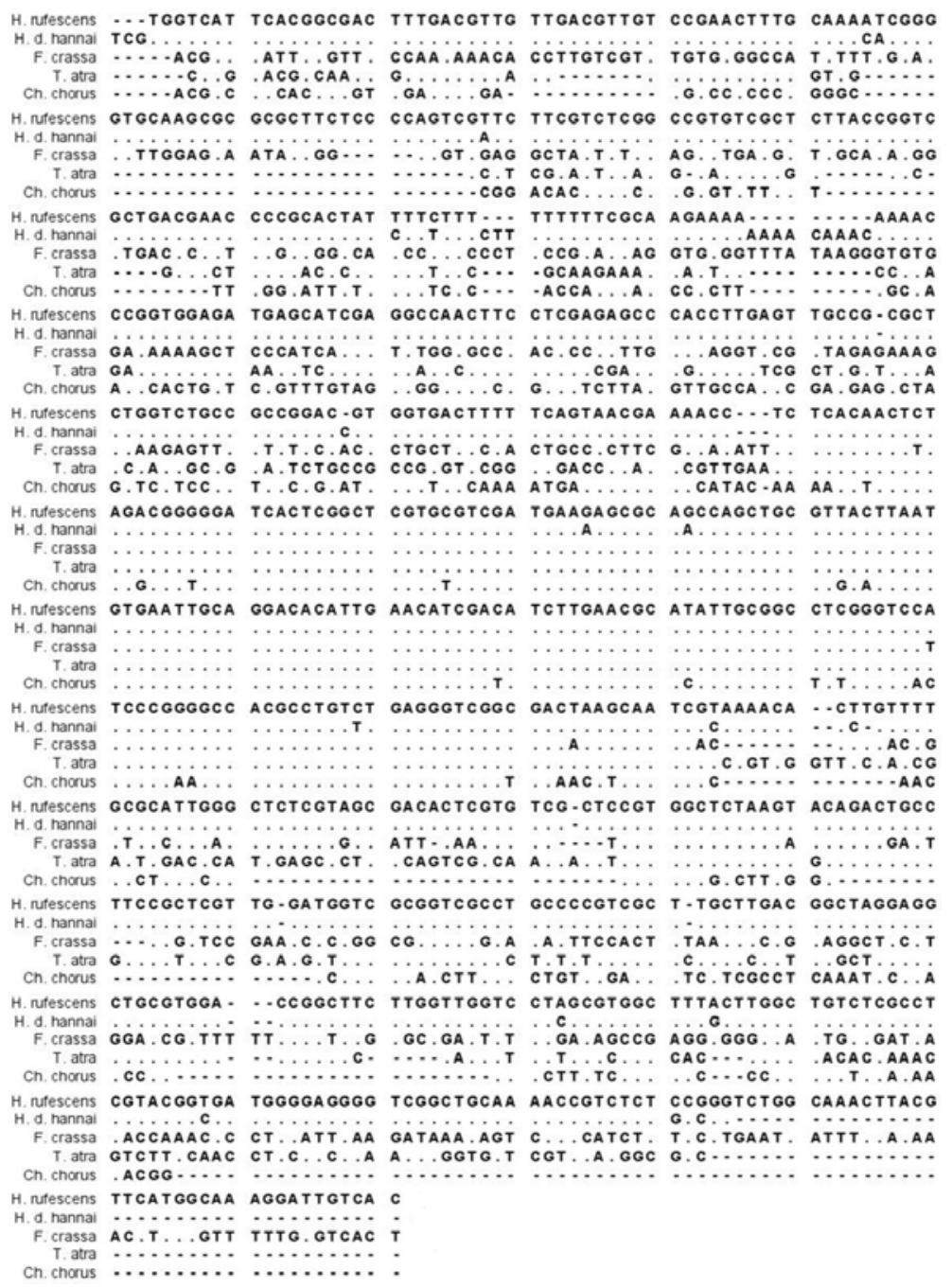

FIGURE 1. Sequence alignment for the ribosomal region ITS1-5.8S rDNA-ITS2 of Chilean commercial mollusk species. (The gaps are indicated by a dash, the sites with nucleotides are indicated with a dot).

FIGURA 1. Alineamiento de las secuencias de la región ribosomal ITS1-5.8S ADNr-ITS2 de las especies de moluscos comerciales en Chile. (Los gaps están indicados por un guión, los sitios con nucleótidos idénticos están indicados con un punto).

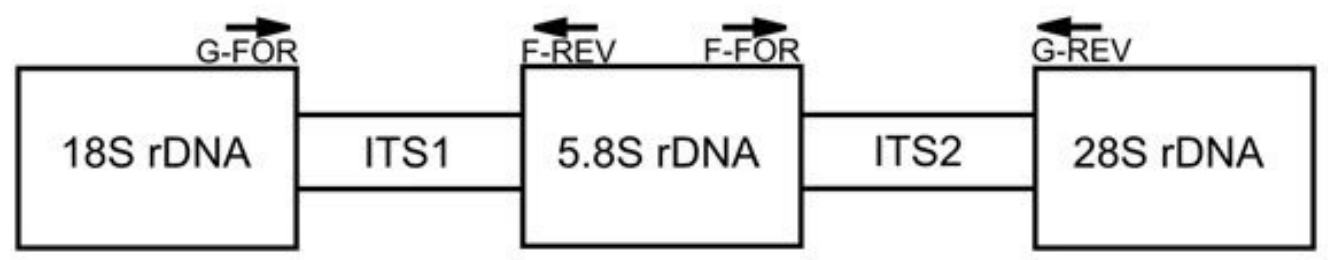

FIGURE 2. Approximate location of the primers used to amplify ITS1 and ITS2. ITS $1=$ internal transcribed spacer 1. ITS 2 = internal transcribed spacer 2 .

FIGURA 2. Localización aproximada de los partidores usados para amplificar ITS1 e ITS2. ITS 1 = espaciador interno transcrito 1 . ITS 2 = espaciador interno transcrito 2. 
Authentication of commercial Chilean mollusks using internal transcribed spacer: AguiLeRA, F. ET AL.

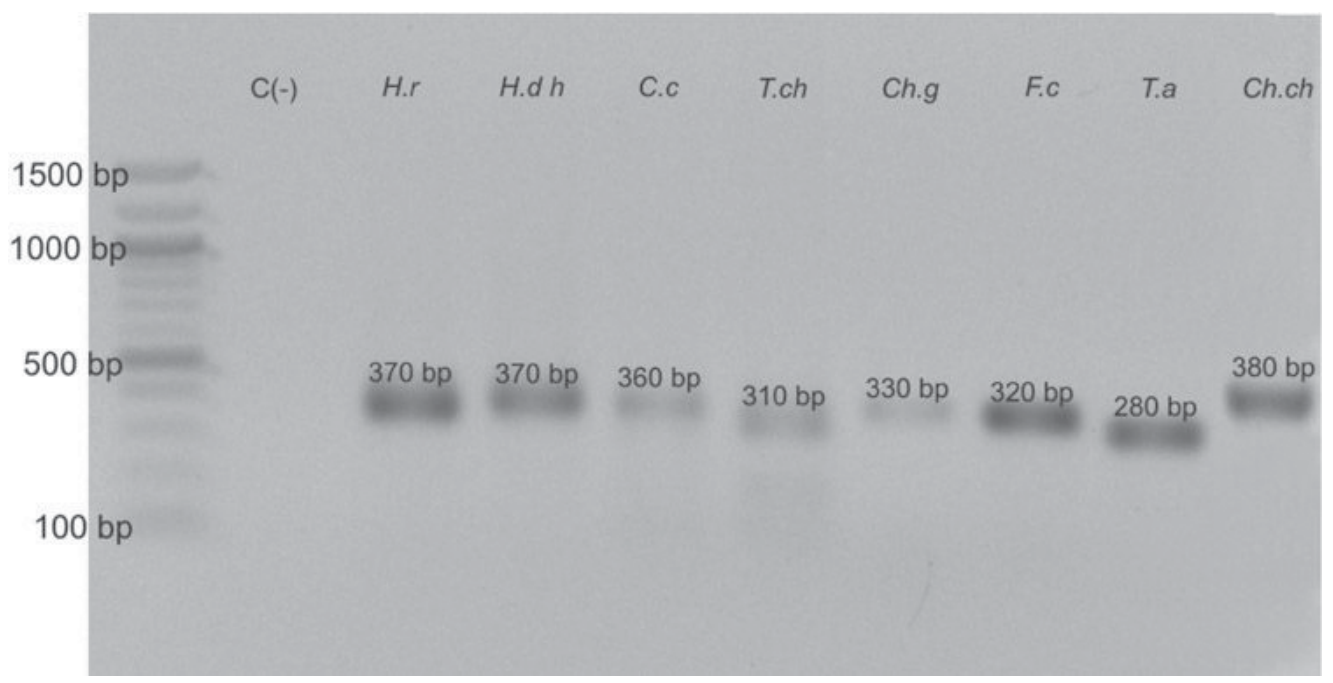

FIgURE 3. Amplification of the internal transcribed spacer 1 in the fresh mollusk products. C (-) mix PCR without DNA H. r: H. rufescens, H. d h: H. discus hannai, C. c: C. concholepas, T. ch: T. chocolata, Ch. g: Ch. giganteus, F. c: F. crassa, T. a: T. atra, Ch. ch: Ch. chorus. Molecular weight marker of 100 b New England BioLabs ${ }^{\circledR}$.

Figura 3. Amplificación del espaciador interno transcrito 1 en los productos frescos de moluscos. C (-) mix PCR sin ADN, H. r: H. rufescens, H. d h: H. discus hannai, C. c: C. concholepas, T. ch: T. chocolata, Ch. g: Ch. giganteus, F. c: F. crassa, T. a: T. atra, Ch. ch: Ch. chorus. Marcador de peso molecular de 100 pb New England BioLabs ${ }^{\circledR}$.

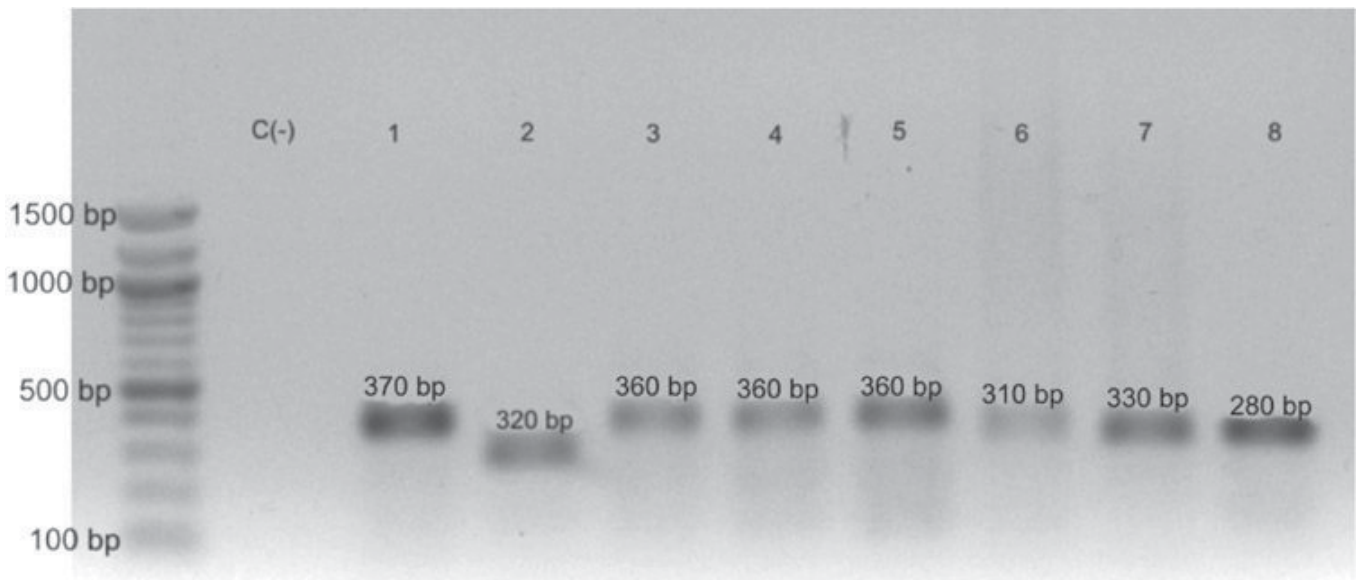

FIgURE 4. Amplification of the internal transcribed spacer 1 in canned and processed mollusk products. C (-): mix PCR without DNA, 1: Canned Oro del Pacífico abalone, 2: Canned Supreme abalone 3: Canned Don Efe Super Extra abalone, 4: Canned Don Efe abalone, 5: Canned Robinson Crusoe loco, 6: T. chocolata processed, 7: Ch. giganteus processed, 8: T. atra processed. Molecular weight marker of 100 bp New England BioLabs ${ }^{\circledR}$.

Figura 4. Amplificación del espaciador interno transcrito 1 en los productos enlatados y procesados de moluscos. C (-): mix PCR sin ADN, 1: Lata Oro del Pacífico abalón, 2: Lata Supreme abalón, 3: Lata Don Efe Super Extra abalón, 4: Lata Don Efe abalón, 5: Lata Robinson Crusoe loco, 6: T. chocolata procesado, 7: Ch. giganteus procesado, 8: T. atra procesado. Marcador de peso molecular de 100 pb New England BioLabs ${ }^{\circledR}$. 


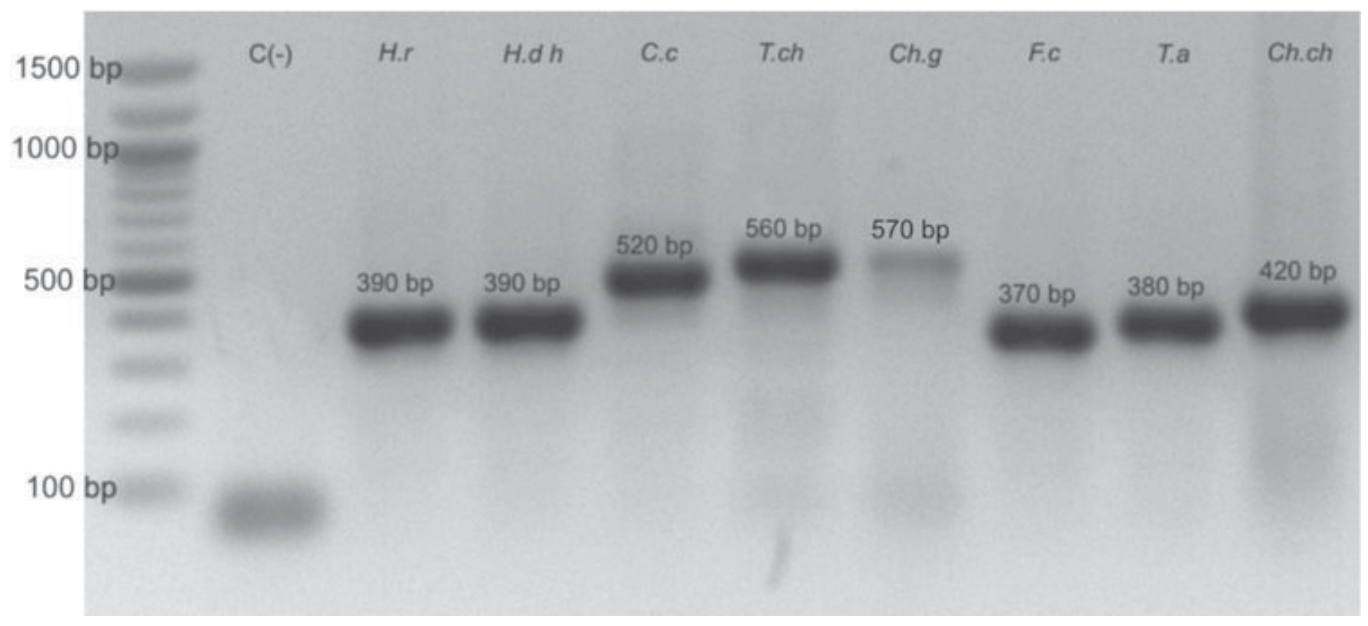

Figure 5. Amplification of the internal transcribed spacer 2 in the fresh mollusk products. C (-) mix PCR with DNA, H. r: H. rufescens, H. d h: H. discus hannai, C. c: C. concholepas, T. ch: T. chocolata, Ch. g: Ch. giganteus, F. c: F. crassa, T. a: T. atra, Ch. ch: Ch. chorus. Molecular weight marker of 100 bp New England BioLabs ${ }^{\circledR}$.

Figura 5. Amplificación del espaciador interno transcrito 2 en los productos frescos de moluscos. C (-) mix PCR sin ADN, H. r: H. rufescens, H. d h: H. discus hannai, C. c: C. concholepas, T. ch: T. chocolata, Ch. g: Ch. giganteus, F. c: F. crassa, T. a: T. atra, Ch. ch: Ch. chorus. Marcador de peso molecular de 100 pb New England BioLabs ${ }^{\circledR}$.

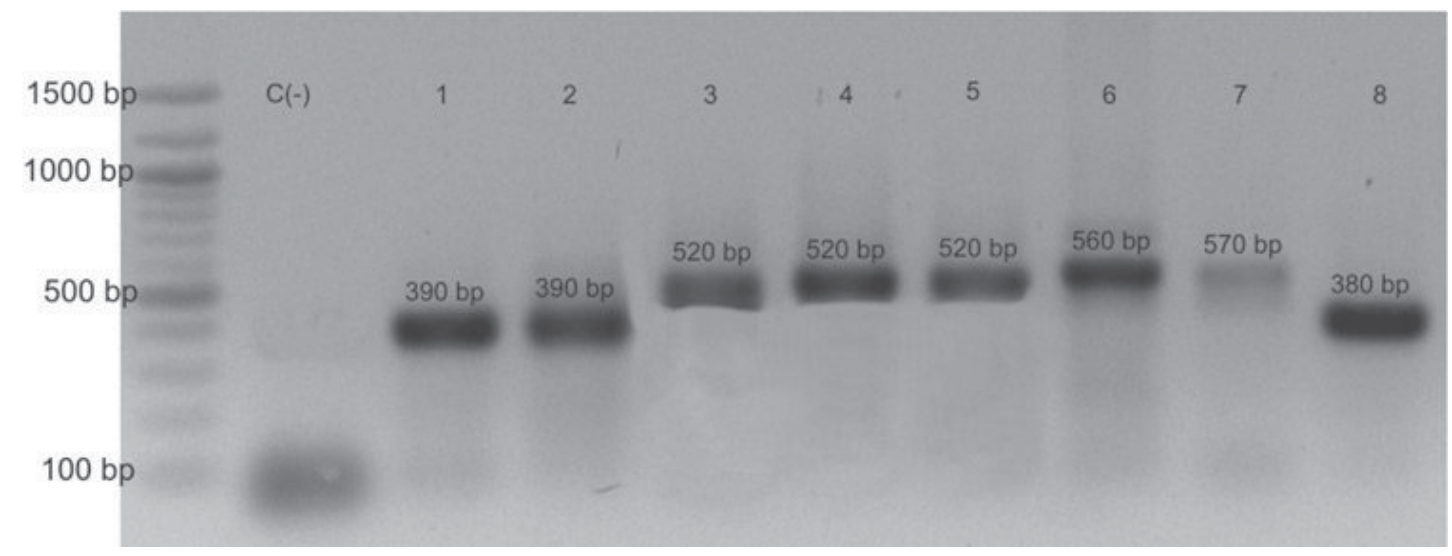

FIGURE 6. Amplification of the internal transcribed spacer 2 in the canned and processed mollusk products. C (-): mix PCR without DNA, 1: Canned Oro del Pacífico abalone, 2: Canned Supreme abalone, 3: Canned Don Efe Super Extra abalone, 4: Canned Don Efe abalone, 5: Canned Robinson Crusoe loco, 6: T. chocolata processed, 7: Ch. giganteus processed, 8: T. atra processed. Molecular weight marker of 100 bp New England BioLabs ${ }^{\circledR}$.

Figura 6. Amplificación del espaciador interno transcrito 2 en los productos enlatados y procesados de moluscos. C (-): mix PCR sin ADN, 1: Lata Oro del Pacífico abalón, 2: Lata Supreme abalón, 3: Lata Don Efe Super Extra abalón, 4: Lata Don Efe abalón, 5: Lata Robinson Crusoe loco, 6: T. chocolata procesado, 7: Ch. giganteus procesado, 8: T. atra procesado. Marcador de peso molecular de 100 pb New England BioLabs ${ }^{\circledR}$. 
In this sense, the variety that the internal transcribed spacers (ITS) have in relation to the size between the species can be used as a good molecular marker for species authentication (Cunningham 1997; Odorico \& Miller 1997; Fernández et al. 2001; Coleman \& Vacquier 2002; López-Piñón et al. 2002; Han-Liang et al. 2006). Specie-specific DNA markers, based on results from electrophoretic patterns, reduce the costs and time involved when analyzing the sequence of PCR products.

In commercially valuable animal products, frauds by substitution with related species of a lower value has been found in many industries in the last few years, resulting in economic losses at a world wide level (López et al. 2003). In this context, the implementation of traceability systems and animal authentication at a genetic level are of great importance for the expansion and diversification of international markets (Loftus 2005). Indeed, Abdulmawjood \& Bülte (2001) developed PCR-RFLP markers of the mitochondrial genes $12 \mathrm{~S}$ rRNA and 16S rRNA to discriminate between the species of land snails Helix pomatia and Helix lucorum due to $H$. pomatia's high market price in Europe. Additionally, the authors developed specie-specific for a variable zone of the 16S rRNA gene. In other sea products, Cocolin et al. (2000) identified fish filets using the markers PCR-RFLP of the cytochrome $b$ gene in order to identify 5 fish species used as substitutes. Carrera et al. (1999) through PCR-RFLP of the mitochondrial 16S rRNA gene obtained specific banding patterns to differentiate between smoked salmon and trout species. Chapela et al. (2002) authenticated cephalopod species through FINS proving the presence of products labeled as Octopus that were really the lower commercially valued species Ilex argentinus. On the other hand, Di-Finizio et al. (2007) identified 7 fish species of different bio-geographic origins through sequence analysis of the 12S rRNA and 16S rRNA genes, where the PCR-RFLP of the 16S rRNA gene allowed rapid discrimination between the species.

Aquaculture, principally lead by salmonidae, mollusks, and seaweeds, exercises a fundamental role in Chilean economic development. In this context, Chile has reached an important development in aquaculture, with exports near US\$ 3.826 billion in the year 2007. Among the most commercially important products, bivalve and gastropod mollusks have shown a significant increase in the last years.
One of the most commercially valuable gastropod species is abalones (26.5 US\$/kg FOB), whose production during 2006 positioned Chile as the 5 th producer at a worldwide level. Given the high values of the halitosis in the international market, fraud by related species substitution has been observed in products canned and labeled as abalone (Sweijd et al. 1998). Exceptionally, this study, using ITS markers, showed that a species substitution between abalone (Haliotis) and loco (Concholepas) in the Don Efe Super Extra and Don Efe cans, which were labeled as "abalone/abulon”. The PCR products amplified with the primers described in the present study for ITS2 show that the haliotids possesses a characteristically allele size of $390 \mathrm{bp}$ in comparison with those observed for the muricid $C$. Concholepas at $520 \mathrm{bp}$. The amplifications generated for ITS1 show that the haliotids possesses a allele size of 370 bp while the muricid C. concholepas is $360 \mathrm{bp}$. Previously, sequence analysis of the 16S rRNA gene using the FINS technique demonstrates the substitution of abalone by other species such as keyhole limpet, "locos”, snails and squids (Del RíoPortilla et al. 2008).

The present study is the first to trace aquaculture products in order to certify and guarantee the quality of the principal food products exported by Chile. The primers proposed can be used in species identification, food traceability practices, phylogenetic studies, and population genetic studies, among others.

\section{ACKNOWLEDGMENTS}

This study was financed by FONDEF Grant D06I1027, D07/1085 and INNOVA 07CT9 PDT79. The authors thank Dr. Miguel Angel del RíoPortilla for his suggestions and comments on the original version of the manuscript.

\section{BIBLIOGRAPHY}

Abdulmawjood, A. \& M. Bülte. 2001. Snail species identification by RFLP-PCR and designing of species-specific oligonucleotide primers. Journal of Food Science. 66 (9): 1287-1293.

Aguilera-Muñoz, F. \& C. Gallardo-Escárate. 2008. Phylogenetics relationship of commercial gastropods in Chile based on DNA sequences of 16S rRNA, COI and ITS1-5.8SrDNA-ITS2. 
Borgo, R., C. Souty-Grosset, D. Bouchon \& L. Gomot. 1996. PCR-RFLP analysis of mitochondrial DNA for identification of snail meat species. Journal of Food Science. 61 (1): 1-4.

Bossier, P. 1999. Authentication of seafood products by DNA patterns. Journal of Food Science. 64 (2): 189-193.

Carrera, E., T. García, A. Céspedes, I. González, A. Fernández, P. E. Hernández \& R. Martín. 1999. PCR-RFLP of the mitochondrial cytochrome oxidase gene: A simple method for discrimination between Atlantic salmon (Salmo salar) and rainbow trout (Oncorhynchus mykiss). Journal of the Science of Food and Agriculture. 79: 16541658.

Chapela, M. J., C. G. Sotelo, P. Calo-Mata, R. I. PérezMartín, H. Rehbein, G. L. Hold, J. Quinteiro, M. Rey-Méndez, C. Rosa \& A. T. Santos. 2002. Identification of cephalopod species (Ommastrephidae and Loliginidae) in seafood products by Forensically Informative Nucleotide Sequencing (FINS). Journal of Food Science. 67 (5): 1672-1676.

Chapela, M. J., C. G. Sotelo \& R. I. Pérez-Martin. 2003. Molecular identification of cephalopod species by FINS and PCR-RFLP of a cytochrome b gene fragment. European Food Research and Technology. 217: 524-529.

Chikuni, K., K. Ozutsumi, T. Koishikawa \& S. Kato. 1990. Species identification of cooked meats by DNA hybridization assay. Meat Science. 27: 119-128.

Cocolin, L., E. D’Agaro, M. Manzano, D. Lanari \& G. ComI. 2000. Rapid PCR-RFLP method for the identification of marine fish fillets (Seabass, Seabream, Umbrine and Dentex). Journal of Food Science. 65 (8): 1315-1317.

Coleman, A. W. 2003. ITS2 is a double-edged tool for eukaryote evolutionary comparisons. Trends in Genetics. 19 (7): 370-375.

Coleman, A. W. \& V. D. Vacquier. 2002. Exploring the phylogenetic utility of ITS sequences for animals: A test case for abalone (Haliotis). Journal of Molecular Evolution. 54: 246-257.

Cunningham, C. O. 1997. Species variation within the internal transcribed spacer (ITS) region of Gyrodactylus (Monogenea: Gyrodactylidae) ribosomal RNA genes. The Journal of Parasitology. 83 (2): 215 - 219.

Cunningham, E. P. \& C. M. Meghen. 2001. Biological identifications systems: Genetic markers. Revue Scientifique et Technique (International Office of Epizootics). 20 (2): 491-499.

del Río-Portilla, M. Á., J. A. Miranda-Velasco, F. Aguilera-Muñoz \& C. Gallardo-Escárate. 2008. Species identification of canned "abalone" using the 16S rRNA by forensically informative nucleotide sequencing. Journal of Food Science. In press.

Di-Finizio, A., G. Guerriero, G. L. Russo \& G. Ciarcia. 2007. Identification of gadoid species (Pisces,
Gadidae) by sequencing and PCR-RFLP analysis of mitochondrial $12 \mathrm{~S}$ and $16 \mathrm{~S}$ rRNA gene fragments. European Food Research and Technology. 225: 337-344.

Fernández, A., T. García, M. Á. Rodríguez, I. GonzÁlez, P. E. HeRnÁndez \& R. MARTín. 2001. PCR-RFLP analysis of the internal transcribed spacer (ITS) region for identification of 3 clam species. Journal of Food Science. 66 (5): 657-661.

Flores-Aguilar, R., A. Gutiérrez, A. Ellwanger \& R. SEARCY-BERnAL. 2007. Development and current status of abalone aquaculture in Chile. Journal of Shellfish Research. 26 (3): 705-711.

Han-Liang, C., M. Xue-Ping, J. Hong-Ju, D. Zhi-Guo \& C. Shu-Yin. 2006. Sequence analysis of the ribosomal DNA internal transcribed spacers and 5.8S ribosomal RNA gene in representatives of the clam family Veneridae (Mollusca: Bivalvia). Journal of Shellfish Research. 25 (3): 833-839.

Higgins, D., J. Thompson \& T. GiBson. 1994. CLUSTAL $\mathrm{W}$ : improving the sensitivity of progressive multiple sequence alignment through sequence weighting, position-specific gap penalties and weight matrix choice. Nucleic Acids Research. 22: 4673-4680.

Insúa, A., M. J. López-Piñón, R. Freire \& J. Méndez. 2003. Sequence analysis of the ribosomal DNA internal transcribed spacer region in some scallop species (Mollusca: Bivalvia: Pectinidae). Genome. 46: 595-604.

Lockley, A. K. \& R. G. BARdsley. 2000. DNA-based methods for food authentification. Trends in Food Science \& Technology. 11: 67-77.

LoFTus, R. 2005. Traceability of biotech-derived animals: Application of DNA technology. Revue Scientifique et Technique (International Office of Epizootics). 24 (1): 231-242.

López-Piñón, M. J., A. Insua \& J. Méndez. 2002. Identification of four scallop species using PCR and restriction analysis of the ribosomal DNA internal transcribed spacer region. Marine Biotechnology. 4: 495-502.

LóPez, M., P. MALlorQuín \& M. Vega. 2003. Tecnologías Moleculares de Trazabilidad Alimentaria. Genoma España Sector agroalimentario, Madrid. 78 pp.

Odorico, D. M. \& D. J. Miller. 1997. Variation in the ribosomal internal transcribed spacer and 5.8S rDNA among five species of Acropora (Cnidaria: Scleractinia): Patterns of variation consistent with reticulate evolution. Molecular Biology and Evolution. 14 (5): 465-473.

Quinteiro, J., C. G. Sotelo, H. Rehbein, S. Pryde, I. Medina, R. I. Pérez-Martin, M. Rey-Méndez \& I. M. Mackie. 1998. Use of mtDNA direct polymerase chain reaction (PCR) sequencing and PCR-Restriction fragment lenght polymorphism methodologies in species identification of canned tuna. Journal of Agricultural and Food Chemistry. 46: 1662-1669. 
Authentication of commercial Chilean mollusks using internal transcribed spacer: AguilerA, F. ET AL.

Ram, J. L., M. L. Ram \& F. F. Baidoun. 1996. Authentication of canned tuna and bonito by sequence and restriction site analysis of polymerase chain reaction products of mitochondrial DNA. Journal of Agricultural and Food Chemistry. 44: 2460-2467.

Regattieri, A., M. Gamberi \& R. Manzini. 2007. Traceability of food products: General framework and experimental evidence. Journal of Food Engineering. 81: 347-356.

Santaclara, F. J., M. Espiñeira, A. G. Cabado, A. Aldasoro, N. González-Lavín \& J. M. Vieites. 2006. Development of a method for the genetic identification of mussel species belonging to Mytilus, Perna, Aulacomya, and other genera. Journal of Agricultural and Food Chemistry. 54: 8461-8470.

SUBPESCA. 2007. Informe Sectorial de Pesca y Acuicultura. Subsecretaría de Pesca 22 pp.
Sweijd, N.A., R.C.K. Bowie, A.L. Lopata, A.M. Marinaki, E.H. Harley \& P.A. Cook. 1998. A PCR technique for forensic, species.level identification of abalone issue. Journal of Shellfish Research. 17: 889-895.

Tamura, K., J. Dudley, M. Nei \& S. Kumar. 2007. MEGA 4: Molecular Evolutionary Genetics Analysis (MEGA) Software version 4.0. Molecular Biology and Evolution. 24 (8): 1596-1599.

Thompson, M., G. Sylvia \& M. T. Morrissey. 2005. Seafood traceability in the United States: Current trends, system design, and potential applications. Comprehensive Reviews in Food Science and Food Safety. 4 (1): 1-7.

Unseld, M., B. Beyermann, P. Brandt \& R. Hiesel. 1995. Identification of the species origin of highly processed meat products by mitochondrial DNA sequences. PCR Methods and Applications. 4: 241-243.

Recibido:17.08.08

Aceptado:15.10.08 